\title{
Adult-onset leukoencephalopathy with homozygous LAMB1 missense mutation
}

Rei Yasuda, MD, PhD, Tomokatsu Yoshida, MD, PhD, Ikuko Mizuta, MD, PhD, Masashi Watanabe, MD, Masakazu Nakano, PhD, Ryuichi Sato, BS, Yuichi Tokuda, PhD, Natsue Omi, PhD, Norio Sakai, MD, PhD, Masanori Nakagawa, MD, PhD, Kei Tashiro, MD, PhD, and Toshiki Mizuno, MD, PhD

Neurol Genet 2020;6:e442. doi:10.1212/NXG.0000000000000442

$L A M B 1$ encodes laminin subunit beta 1 , a constituent of the extracellular matrix glycoprotein of basement membranes. ${ }^{1}$ Mutations of $L A M B 1$ have been reported in patients with congenital or infantile- to childhood-onset leukoencephalopathy and severe developmental retardation. ${ }^{2,3}$ We report an adulthood-onset case with mild leukoencephalopathy and a novel homozygous $\angle A M B 1$ missense mutation. Our findings expand the clinical spectrum of LAMB1-related disorder.

\section{Case report}

A 37-year-old woman with headache, memory loss, and gait disturbance was referred to our department. She was born to consanguineous parents (figure 1A), and her elder sister was asymptomatic. She had been healthy until age 22 years, when migraine developed. Brain MRI showed a cerebral white matter lesion at age 30 years. She developed gait disturbance at age 31 years. She had been aware of memory loss, executive dysfunction, and menstrual irregularity since age 35 years. On neurologic examination, hyperreflexia of jaw jerk and legs and lower limb spasticity were observed. The Wechsler Adult Intelligence Scale-Third Edition indicated a fullscale IQ of 69, suggesting borderline intelligence. Blood test findings were negative/normal for syphilis, HIV, autoantibodies, lactate, pyruvate, and very-long-chain fatty acids. Measurement of enzyme activity did not suggest gangliosidosis, metachromatic leukodystrophy, or Krabbe disease. Ophthalmologic evaluation revealed mild flexion of retinal vessels (figure 1B), but neither optic atrophy nor subcapsular lens opacification. Brain MRI showed diffuse T2 hyperintensity of cerebral white matter, but neither cortical dysgenesis nor cystic lesions were observed (figure 1, C-D). Neurologic examination and brain MRI of her father showed no abnormalities, whereas her mother did not consent to neurologic examination or brain MRI. These suggested autosomal recessive inheritance. We focused exome sequencing analysis on the 115 genes retrieved from Online Mendelian Inheritance in Man (OMIM) ${ }^{4}$ using the terms: "leukoencephalopathy", "leukodystrophy", and "small vessel" and identified 2 potent biallelic pathogenic mutations in LAMB1 (c.1378T>C, p.Cys460Arg) on chromosome 7 and ARSE (c.220G >A, p.Val74Met) on chromosome X. Careful reading of the OMIM text of ARSE revealed that not ARSE (arylsulfatase E) but ARSA (arylsulfatase A) was related to leukodystrophy. Therefore, we focused on LAMB1 and validated the mutation by Sanger sequencing. The parents had heterozygous mutations (figure 1E). LAMB1 p.Cys460Arg was absent in the nucleotide variation databases (gnomAD and $4.7 \mathrm{KJPN})^{4}$ and predicted to be pathogenic by multiple software programs (SIFT, PolyPhen-2, Mutation Taster, PROVEAN, and CADD). ${ }^{4}$ These findings suggest that $L A M B 1$ was a causative gene for leukoencephalopathy in this patient.

\author{
Correspondence \\ Dr. Yasuda \\ ryasuda@koto.kpu-m.ac.jp
}




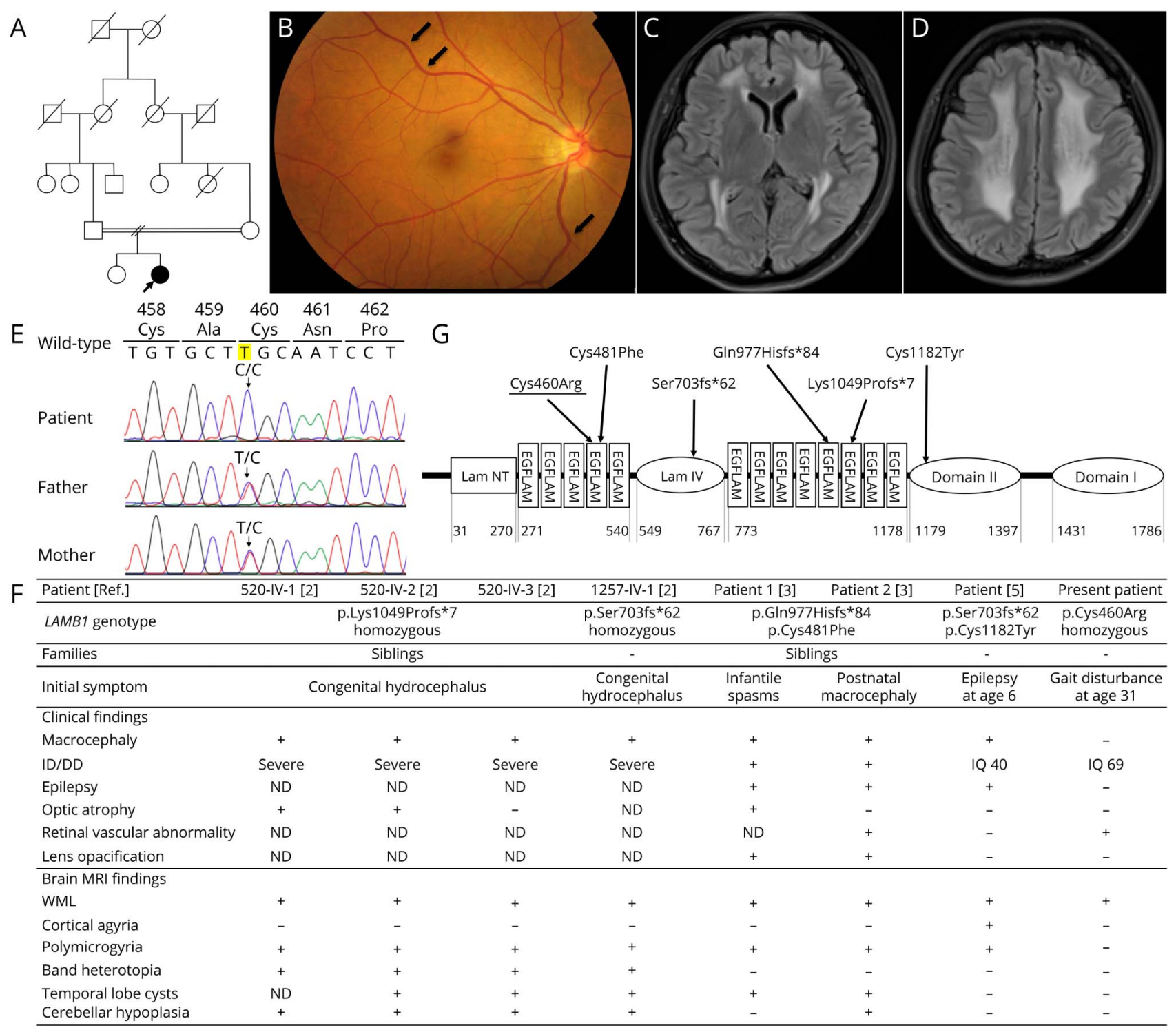

(A) Family tree of the patient (arrow). (B) Fundus image of the right eye shows mild flexion of retinal vessels (arrow). (C and D) Brain MRI at age 40 years. FLAIR axial images show diffuse hyperintensity of white matter. (E) Sanger sequencing of genomic DNA demonstrates that the patient has homozygous C/C, whereas each parent has heterozygous T/C at c.1378T (highlighted in wild-type sequence). (F) Clinical and MRI findings of patients with LAMB1 mutations. ID/DD = intellectual disability/developmental delay; ND = not described; WML = white matter lesions on MRI. (G) Summary of the LAMB1 protein structure and location of mutations. Our case is underlined. EGFLAM = laminin epidermal growth factor-like domain; FLAIR = fluid-attenuated inversion recovery; Lam NT = laminin N-terminal; LAM IV = laminin IV type B.

\section{Discussion}

We report a patient with adult-onset leukoencephalopathy and a homozygous $L A M B 1$ missense mutation. The clinical phenotype included mild intellectual disability and spastic gait. Periventricular rim on brain MRI and retinal vessel abnormalities were features not reported in other adult-onset leukoencephalopathies (table e-1, figure e-1, links.lww.com/NXG/A265).

LAMB1 mutation was originally reported to cause autosomal recessive cobblestone brain malformation, presenting with congenital hydrocephalus, severe developmental delay, and an increased head circumference. ${ }^{2}$ Subsequently, the phenotype of
LAMB1-related disorders was extended to include progressive leukoencephalopathy with seizures, ocular abnormalities, and porencephalic lesions. ${ }^{3}$ Recently, a patient with a relatively milder phenotype, including childhood-onset epilepsy, macrocephaly, and intellectual development arrest, was reported. ${ }^{5}$ Retinal vascular abnormality was reported in a patient with $L A M B 1$ compound hetero mutation, similar to our patient, ${ }^{3}$ which might be a key finding to suspect LAMB1-related basement membrane pathologies.

Comparison of previous cases and the present patient with biallelic $L A M B 1$ mutations indicated genotype-phenotype correlations. Homozygous frameshift mutations (p.Lys1049Profs*7 
and p.Ser703fs*62) were identified in the most severe congenital-onset patients (figure $1 \mathrm{~F}$ ). ${ }^{2}$ Compound heterozygous mutations including 1 missense mutation (p.Gln977Hisfs*84/ p.Cys481Phe and p.Ser703fs*62/p.Cys1182Tyr) were identified in less severe patients with postnatal to childhood onsets. ${ }^{3,5}$ Our patient with homozygous missense mutations showed a much milder phenotype. Taken together, the effect of missense mutations on the phenotype may be milder compared with that of frameshift mutations.

Localization of 5 mutations previously reported and that identified by us in LAMB1 protein is shown (figure 1G). Frameshift mutations are considered to result in truncating protein, suggesting loss-of-function effects. The effect of p.Cys480Phe and p.Cys460Arg may be conformational change because each EGFlike repeat contains 8 cysteine residues participating in 4 pairs of disulfide bonds that determine appropriate protein conformation. ${ }^{1}$ Similarly, in cerebral autosomal dominant arteriopathy with subcortical infarcts and leukoencephalopathy, cysteinerelated missense mutations in a certain EGF-like repeat were confirmed as pathogenic. ${ }^{6,7}$ Further molecular analysis will clarify the effects of $L A M B 1$ missense mutations.

In conclusion, our findings expand the clinical spectrum of $L A M B 1$-related disorder. $L A M B 1$ gene mutation should be considered in the setting of adult-onset autosomal recessive leukoencephalopathy with retinal vascular abnormality.

\section{Data availability}

The data sets generated during and/or analyzed during the current study are available from the corresponding author on reasonable request.

\section{Study funding}

Supported by Intractable Disease Research Grants from the Ministry of Health, Labour and Welfare of the Government of Japan (H30-Nanchitou(Nan)-Ippan-008) and JSPS KAKENHI (16K09698).

\section{Disclosure}

The authors report no disclosures relevant to the manuscript. Go to Neurology.org/NG for full disclosures.

\section{Publication history}

Received by Neurology: Genetics March 11, 2020. Accepted in final form April 20, 2020.

\section{Appendix Authors}

\begin{tabular}{lll}
\hline Name & Location & Contribution \\
\hline $\begin{array}{lll}\text { Rei Yasuda, } \\
\text { MD, PhD }\end{array}$ & $\begin{array}{l}\text { Department of Neurology, } \\
\text { Graduate School of Medical } \\
\text { Science, Kyoto Prefectural }\end{array}$ & $\begin{array}{l}\text { Design and } \\
\text { conceptualization of the } \\
\text { Study; major role in the }\end{array}$ \\
& $\begin{array}{l}\text { University of Medicine, } \\
\text { Kyoto, Japan }\end{array}$ & $\begin{array}{l}\text { acquisition of data; analysis } \\
\text { and interpretation of the } \\
\text { data; and drafting and } \\
\end{array}$ \\
& $\begin{array}{l}\text { revision of the manuscript } \\
\text { for intellectual content }\end{array}$ \\
\end{tabular}

Appendix (continued)

\begin{tabular}{|c|c|c|}
\hline Name & Location & Contribution \\
\hline $\begin{array}{l}\text { Tomokatsu } \\
\text { Yoshida, } \\
\text { MD, PhD }\end{array}$ & $\begin{array}{l}\text { Department of Neurology, } \\
\text { Graduate School of Medical } \\
\text { Science, Kyoto Prefectural } \\
\text { University of Medicine, } \\
\text { Kyoto, Japan }\end{array}$ & $\begin{array}{l}\text { Design and } \\
\text { conceptualization of the } \\
\text { study; interpretation of the } \\
\text { data; and drafting and } \\
\text { revision of the manuscript } \\
\text { for intellectual content }\end{array}$ \\
\hline $\begin{array}{l}\text { Ikuko } \\
\text { Mizuta, MD, } \\
\text { PhD }\end{array}$ & $\begin{array}{l}\text { Department of Neurology, } \\
\text { Graduate School of Medical } \\
\text { Science, Kyoto Prefectural } \\
\text { University of Medicine, } \\
\text { Kyoto, Japan }\end{array}$ & $\begin{array}{l}\text { Major role in the } \\
\text { acquisition of data; analysis } \\
\text { and interpretation of the } \\
\text { data; and drafting and } \\
\text { revision of the } \\
\text { manuscript for } \\
\text { intellectual content }\end{array}$ \\
\hline
\end{tabular}

\begin{tabular}{lll}
\hline Masashi & Department of Neurology, & Major role in the \\
Watanabe, & Ehime Prefectural Central & acquisition of data; \\
MD & Hospital, Ehime, Japan & $\begin{array}{l}\text { interpretation of the data; } \\
\text { and revision of the } \\
\text { manuscript for intellectual } \\
\text { content }\end{array}$
\end{tabular}

\begin{tabular}{ll}
\hline Masakazu & Department of Genomic \\
Nakano, & Medical Sciences, Kyoto \\
PhD & Prefectural University of \\
& Medicine, Kyoto, Japan
\end{tabular}

Design of the study; major role in the acquisition of data; analysis and interpretation of the data; and revision of the manuscript for intellectual content

\begin{tabular}{lll}
\hline Ryuichi & Department of Genomic & Major role in the \\
Sato, BS & Medical Sciences, Kyoto & acquisition of data; analysis \\
& Prefectural University of & $\begin{array}{l}\text { and interpretation of the } \\
\text { data; and revision of the } \\
\text { Medicine, Kyoto, Japan }\end{array}$ \\
& $\begin{array}{l}\text { manuscript for intellectual } \\
\text { content }\end{array}$
\end{tabular}

\begin{tabular}{ll}
\hline Yuichi & Department of Genomic \\
Tokuda, & Medical Sciences, Kyoto \\
PhD & Prefectural University of
\end{tabular}

Major role in the acquisition of data; analysis and interpretation of the data; and revision of the manuscript for intellectual content

\begin{tabular}{|c|c|c|}
\hline $\begin{array}{l}\text { Natsue } \\
\text { Omi, PhD }\end{array}$ & $\begin{array}{l}\text { Department of Genomic } \\
\text { Medical Sciences, Kyoto } \\
\text { Prefectural University of } \\
\text { Medicine, Kyoto, Japan }\end{array}$ & $\begin{array}{l}\text { Major role in the } \\
\text { acquisition of data and } \\
\text { revision of the manuscript } \\
\text { for intellectual content }\end{array}$ \\
\hline $\begin{array}{l}\text { Norio } \\
\text { Sakai, MD, } \\
\text { PhD }\end{array}$ & $\begin{array}{l}\text { Child Healthcare and } \\
\text { Genetic Science } \\
\text { Laboratory, Division of } \\
\text { Health Sciences, Osaka } \\
\text { University Graduate } \\
\text { School of Medicine, } \\
\text { Osaka, Japan }\end{array}$ & $\begin{array}{l}\text { Major role in the } \\
\text { acquisition of data; analysis } \\
\text { and interpretation of the } \\
\text { data; and revision of the } \\
\text { manuscript for intellectual } \\
\text { content }\end{array}$ \\
\hline $\begin{array}{l}\text { Masanori } \\
\text { Nakagawa, } \\
\text { MD, PhD }\end{array}$ & $\begin{array}{l}\text { Department of Neurology, } \\
\text { North Medical Center, } \\
\text { Kyoto Prefectural } \\
\text { University of Medicine, } \\
\text { Kyoto, Japan }\end{array}$ & $\begin{array}{l}\text { Conceptualization of the } \\
\text { study and revision of the } \\
\text { manuscript for intellectual } \\
\text { content }\end{array}$ \\
\hline $\begin{array}{l}\text { Kei Tashiro, } \\
\text { MD, PhD }\end{array}$ & $\begin{array}{l}\text { Department of Genomic } \\
\text { Medical Sciences, Kyoto } \\
\text { Prefectural University of } \\
\text { Medicine, Kyoto, Japan }\end{array}$ & $\begin{array}{l}\text { Design and } \\
\text { conceptualization of the } \\
\text { study and revision of the } \\
\text { manuscript for intellectual } \\
\text { content }\end{array}$ \\
\hline $\begin{array}{l}\text { Toshiki } \\
\text { Mizuno, } \\
\text { MD, PhD }\end{array}$ & $\begin{array}{l}\text { Department of Neurology, } \\
\text { Graduate School of Medical } \\
\text { Science, Kyoto Prefectural } \\
\text { University of Medicine, } \\
\text { Kyoto, Japan }\end{array}$ & $\begin{array}{l}\text { Conceptualization of the } \\
\text { study; major role in the } \\
\text { acquisition of data; } \\
\text { interpretation of the data; } \\
\text { and revision of the } \\
\text { manuscript for intellectual } \\
\text { content }\end{array}$ \\
\hline
\end{tabular}




\section{References}

1. Aumailley M. The laminin family. Cell Adh Migr 2013;7:48-55.

2. Radmanesh F, Caglayan AO, Silhavy JL, et al. Mutations in LAMB1 cause cobblestone brain malformation without muscular or ocular abnormalities. Am J Hum Genet 2013;92:468-474.

3. Tonduti D, Dorboz I, Renaldo F, et al. Cystic leukoencephalopathy with cortical dysplasia related to LAMB1 mutations. Neurology 2015;84:2195-2197.

4. Online Mendelian Inheritance in Man (OMIM). Available at: omim.org, accessed March 6, 2018; Genome Aggregation Database (gnomAD). Available at: gnomad. broadinstitute.org, accessed February 4, 2020; 4.7KJPN. Available at: jmorp.megabank.tohoku.ac.jp, accessed February 4, 2020; Sorting Intolerant From Tolerant (SIFT). Available at: sift.bii.a-star.edu.sg, accessed February 4, 2020; Polymorphism Phenotyping v2 (PolyPhen-2). Available at: genetics.bwh.harvard.edu/pph2, accessed
February 4, 2020; Mutation Taster. Available at: www.mutationtaster.org, accessed February 4, 2020; Protein Variation Effect Analyzer (PROVEAN). Available at: provean.jcvi.org/index.php, accessed February 4, 2020; Combined Annotation Dependent Depletion (CADD). Available at: cadd.gs.washington.edu, accessed February 4, 2020.

5. Okazaki T, Saito Y, Hayashida T, et al. Bilateral cerebellar cysts and cerebral white matter lesions with cortical dysgenesis: Expanding the phenotype of LAMB1 gene mutations. Clin Genet 2018;94:391-392.

6. Wang T, Baron M, Trump D. An overview of Notch3 function in vascular smooth muscle cells. Prog Biophys Mol Biol 2008;96:499-509.

7. Chabriat H, Joutel A, Dichgans M, Tournier-Lasserve E, Bousser MG. Cadasil. Lancet Neurol 2009;8:643-653. 


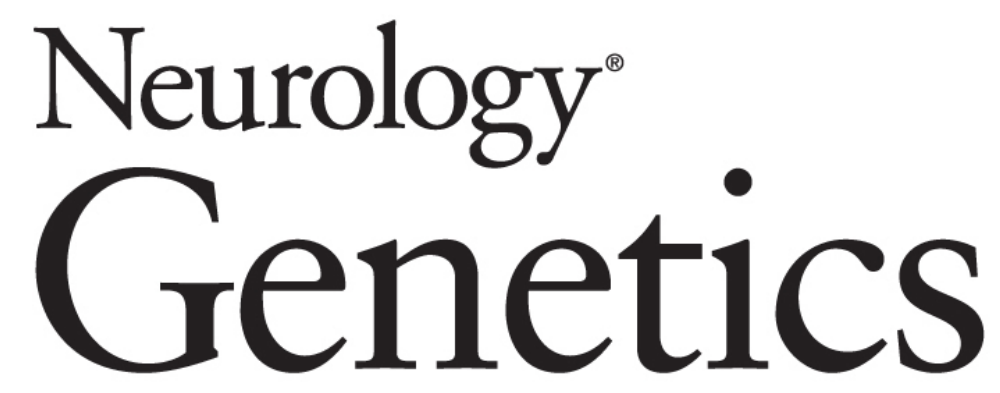

\section{Adult-onset leukoencephalopathy with homozygous LAMB1 missense mutation}

Rei Yasuda, Tomokatsu Yoshida, Ikuko Mizuta, et al.

Neurol Genet 2020;6;

DOI 10.1212/NXG.0000000000000442

\section{This information is current as of May 19, 2020}

\section{Updated Information \& Services}

References

Subspecialty Collections

Permissions \& Licensing

Reprints including high resolution figures, can be found at: http://ng.neurology.org/content/6/4/e442.full.html

This article cites 6 articles, 0 of which you can access for free at: http://ng.neurology.org/content/6/4/e442.full.html\#\#ref-list-1

This article, along with others on similar topics, appears in the following collection(s):

\section{All Genetics}

http://ng.neurology.org//cgi/collection/all_genetics

Information about reproducing this article in parts (figures,tables) or in its entirety can be found online at:

http://ng.neurology.org/misc/about.xhtml\#permissions

Information about ordering reprints can be found online: http://ng.neurology.org/misc/addir.xhtml\#reprintsus

Neurol Genet is an official journal of the American Academy of Neurology. Published since April 2015, it is an open-access, online-only, continuous publication journal. Copyright Copyright ( 2020 The Author(s). Published by Wolters Kluwer Health, Inc. on behalf of the American Academy of Neurology.. All rights reserved. Online ISSN: 2376-7839.

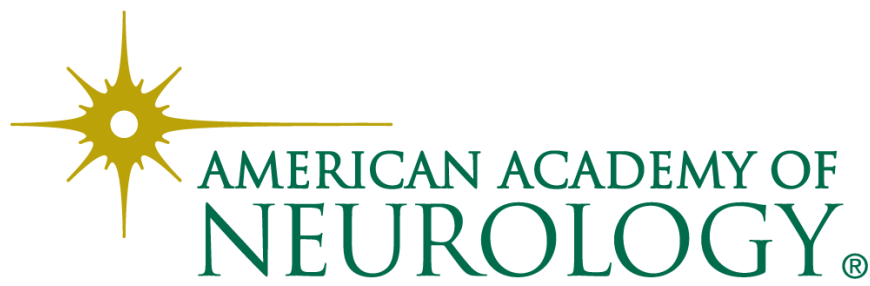

